Article

\title{
Preparation and Characterization of a Novel Amidoxime-Modified Polyacrylonitrile/Fly Ash Composite Adsorbent and Its Application to Metal Wastewater Treatment
}

\author{
Yan Sun ${ }^{1}$, Xiaojun Song ${ }^{1}$, Jing Ma ${ }^{1}\left(\mathbb{D}\right.$, Haochen $\mathrm{Yu}^{2}{ }^{\mathbb{D}}$, Gangjun $\mathrm{Liu}^{3}$ and Fu Chen ${ }^{1,2, *(\mathbb{D})}$ \\ 1 School of Public Administration, Hohai University, Nanjing 210098, China; suny@hhu.edu.cn (Y.S.); \\ songxiaojun@hhu.edu.cn (X.S.); jingma2013@cumt.edu.cn (J.M.) \\ 2 School of Public Policy, China University of Mining and Technology, Xuzhou 221043, China; \\ haochen.yu@cumt.edu.cn \\ 3 Geospatial Science, School of Science, STEM College, RMIT University, Melbourne 3000, Australia; \\ gang-jun.liu@rmit.edu.au \\ * Correspondence: chenfu@cumt.edu.cn; Tel.: +86-5168-388-3501
}

check for updates

Citation: Sun, Y.; Song, X.; Ma, J.; Yu, H.; Liu, G.; Chen, F. Preparation and Characterization of a Novel Amidoxime-Modified

Polyacrylonitrile/Fly Ash Composite Adsorbent and Its Application to

Metal Wastewater Treatment. Int. J. Environ. Res. Public Health 2022, 19, 856. https://doi.org/10.3390/ ijerph19020856

Academic Editor: Andre Lerch

Received: 9 December 2021

Accepted: 11 January 2022

Published: 13 January 2022

Publisher's Note: MDPI stays neutral with regard to jurisdictional claims in published maps and institutional affiliations.

Copyright: (C) 2022 by the authors. Licensee MDPI, Basel, Switzerland. This article is an open access article distributed under the terms and conditions of the Creative Commons Attribution (CC BY) license (https:// creativecommons.org/licenses/by/ $4.0 /)$.

\begin{abstract}
The polyacrylonitrile/fly ash composite was synthesized through solution polymerization and was modified with $\mathrm{NH}_{2} \mathrm{OH} \cdot \mathrm{HCl}$. The amidoxime-modified polyacrylonitrile/fly ash composite demonstrated excellent adsorption capacity for $\mathrm{Zn}^{2+}$ in an aqueous medium. Fourier transformInfrared spectroscopy, thermogravimetric analysis, nitrogen adsorption, X-ray diffraction, and scanning electron microscopy were used to characterize the prepared materials. The results showed that the resulting amidoxime-modified polyacrylonitrile/fly ash composite was able to effectively remove $\mathrm{Zn}^{2+}$ at $\mathrm{pH} 4-6$. Adsorption of $\mathrm{Zn}^{2+}$ was hindered by the coexisting cations. The adsorption kinetics of $\mathrm{Zn}^{2+}$ by $\mathrm{Zn}^{2+}$ followed the pseudo-second order kinetic model. The adsorption process also satisfactorily fit the Langmuir model, and the adsorption process was mainly single layer. The Gibbs free energy $\Delta \mathrm{G}^{0}, \Delta \mathrm{H}^{0}$, and $\Delta \mathrm{S}^{0}$ were negative, indicating the adsorption was a spontaneous, exothermic, and high degree of order in solution system.
\end{abstract}

Keywords: amidoxime-modified polyacrylonitrile/fly ash composite; fly ash; $\mathrm{Zn}^{2+}$; adsorption

\section{Introduction}

Zinc is an important trace element in the human body and one of the heavy metal elements harmful to nature [1-3]. The harm of zinc to the human body mainly comes from the accumulation of industrial wastewater in water and organisms, which is a potential threat to human health through the food chain [4-6]. With the rapid development of industry, $\mathrm{Zn}^{2+}$ ions enter the environment in different ways. Therefore, it is urgent to treat the wastewater containing $\mathrm{Zn}^{2+}$ ions and solve the toxicity caused by $\mathrm{Zn}^{2+}$ ions [7-10].

At present, there are many industrial methods available for treating $\mathrm{Zn}^{2+}$ in heavy metal wastewater such as chemical precipitation [11], chemical redox [12], filtration [13], ion-exchange [14-16], electrolysis [17], evaporation recovery [18], and adsorption [19-23]. Among them, the adsorption method has the advantages of simple operation, high selectivity, and high purification. The materials used to adsorb $\mathrm{Zn}^{2+}$ ions are activated carbon [24-29], zeolite [30-32], chitosan [33-35], etc.

Fly ash is a kind of industrial byproduct produced by coal combustion, which is a porous material with a loose structure and uniform pore size distribution [36,37]. Fly ash does great harm to the human ecological environment [38]. Furthermore, the amount of fly ash increases with the increase in thermal power generation. Therefore, fly ash should be utilized. In terms of the concept of treating waste with waste, fly ash as an adsorbent has the advantages of easy access, high treatment efficiency, and low cost [39]. However, it is difficult to separate the solid and liquid after adsorption when fly ash is 
used directly. The fly ash has a good adsorption basis, and different treatments of fly ash by relevant methods can give it a higher adsorption efficiency for the target adsorbent. The modification of materials is generally based on structural modification, remodeling of internal pore structure, and surface modification of materials. Among them, structural modification changed the original components of the material, and the modification of internal pore structure mainly changed the size of the internal pores and specific surface area and can change its ion exchange performance. Surface modification referred to the surface treatment of the material, adhesion, or adhesion of other compounds according to the intermolecular affinity. Current research on fly ash showed that the more common modification methods of fly ash include acid-base modification, thermal modification, inorganic salt modification, and organic modification. Deng et al. studied the adsorption characteristics of fly ash modified by microwave-assisted alkali on hexavalent chromium. After microwave assisted modification, the adsorption performance of fly ash on hexavalent chromium was improved about two times, and the adsorption process was single molecule adsorption [40]. Oyehan et al. studied the adsorption capacity of mesoporous fly ash grafted with an ultrathin film of polydiallyldimethyl ammonium for phenol in aqueous solution and found that the particle size of fly ash was related to adsorption. The smaller the particle size was, the larger the specific surface area was, and the saturated adsorption capacity of fly ash for phenol in aqueous solution was $13.05 \mathrm{mg} / \mathrm{g}$ [41]. Tang et al. studied the adsorption and removal capacity of fly ash for $\mathrm{Zn}^{2+}$ and $\mathrm{Cu}^{2+}$ ions in aqueous solution [42] Hui et al. reported that pure and chamfered-edge zeolite 4A prepared from coal fly ash were effective in removing mixed heavy metal ions for the recycling of fly ash [43]. There are some reports about polymer-modified fly ash used in the field of wastewater treatment. Jiang and Liu [43] reported that copolymer of acrylic acid (AA) and acrylamide (AM) was grafted onto the surface of the $\gamma$-methacryloxypropyl trimethoxy silane (KH-570) modified fly ash by the inverse suspension polymerization process. A novel magnetic fly ash/poly (acrylic acid) (FA/PAA) composite microgel was prepared for adsorption of $\mathrm{Pb}^{2+}$ [44].

Chelating fiber as a high-performance adsorption material has been widely used in many fields such as wastewater treatment [45] and heavy metal ion separation, enrichment, and recovery analysis [46]. Chelating fiber has the advantages of large specific surface area, good adsorption performance, and fast adsorption and desorption rate. In this work, amidoxime-modified polyacrylonitrile/fly ash composite (AO-PAN/FA) was prepared and the adsorption capacity for $\mathrm{Zn}^{2+}$ was investigated in a water solution.

\section{Materials and Methods}

\subsection{Materials}

FA was obtained from Huaneng Hunan Yueyang Power Generation Co., Ltd., Yueyang, China. The FA was treated with $0.10 \mathrm{~mol} / \mathrm{L} \mathrm{HCl}$ solution for $24 \mathrm{~h}$ and then washed and dried at $100{ }^{\circ} \mathrm{C}$ for $24 \mathrm{~h}$.

Acrylonitrile, N,N-methylenebisacrylamide, hydroxylamine $\left(\mathrm{NH}_{2} \mathrm{OH} \cdot \mathrm{HCl}\right)$, ammonium persulfate (APS), Triton $\mathrm{X}-100, \mathrm{Na}_{2} \mathrm{CO}_{3}$, and $\mathrm{ZnCl}_{2}$ were of analytical grade obtained from Tianjin Kaixin Chemical Industry Co., Ltd., Tianjin, China. Distilled water was used throughout the experiments.

\subsection{Preparation of Polyacrylonitrile/Fly Ash Composite}

The FA pretreated with $\mathrm{HCl}$ was ultrasonically treated with water at a ratio of 1:5. Then, a certain amount of Triton X-100 was added and sonicated for $2 \mathrm{~h}$. Then, acrylonitrile and N, N-methylenebisacrylamide were added into the emulsion, and the mixture was sonicated at room temperature for $0.5 \mathrm{~h}$ again, followed by adding APS. The mixture was stirred at room temperature for $0.5 \mathrm{~h}$ and then at $60{ }^{\circ} \mathrm{C}$ for $3 \mathrm{~h}$ under $\mathrm{N}_{2}$ atmosphere. The polyacrylonitrile/fly ash composite was obtained, which was washed with distilled water and ethanol in turn, extracted in water for $48 \mathrm{~h}$ with Soxhlet extractor and dried. 


\subsection{Preparation of Amidoxime-Modified Polyacrylonitrile/Fly Ash Composite}

Next, $0.5 \mathrm{~g}$ polyacrylonitrile/fly ash composite was added into $150 \mathrm{~mL} 20 \mathrm{~g} / \mathrm{L}$ $\mathrm{NH} 2 \mathrm{OH} \cdot \mathrm{HCl}$ solution, and then $2 \mathrm{~g} \mathrm{Na}_{2} \mathrm{CO}_{3}$ was added. The mixture was heated up to $80{ }^{\circ} \mathrm{C}$ and maintained for a period of time. The amidoxime-modified polyacrylonitrile/fly ash composite was collected by filtration and then washed by alcohol.

\subsection{Characterization}

Fourier transform infrared (FT-IR) spectra of samples were measured using Nicolet 370 FT-IR spectrometer (Thermo Nicolet Corporation, American, Madison, WI, USA). Nitrogen adsorption (Brunauer-Elmett-Teller, BET) was performed with a Surface Area and Pore Size Analyzer (Micromeritics TriStar3000) at $77 \mathrm{~K} / 1$ bar. Thermogravimetric analysis (TGA) was conducted on a SII TG/DTA 6300 thermogravimetric analyzer. X-ray diffraction (XRD) spectra were collected on an Ultima IV X-ray diffractometer (Japan Science Co., Ltd. Tokyo, Japan) using copper $\mathrm{K} \alpha$ radiation at a voltage of $30 \mathrm{kV}$ and $20 \mathrm{~mA}$ over the $2 \theta$ range of $5-90^{\circ}$. The morphology was analyzed using a field emission scanning electron microscope (SEM) supplied by ZEISS (Sigma 300, Cambridge, UK). Atomic absorption spectroscopy (AAS, Shimadzuatomic absorption spectrometer, Kyoto, Japan) was employed to analyze $\mathrm{Zn}^{2+}$ concentration in the adsorption investigation.

\subsection{Adsorption of $\mathrm{Zn}^{2+}$ in Aqueous Solution}

The adsorption experiments were carried out at room temperature. Before the experiments, the standard curve of $\mathrm{Zn}^{2+}$ was measured by AAS. Next, $0.2085 \mathrm{~g} \mathrm{ZnCl} 2$ was dissolved in distilled water and diluted with distilled water to volume to $1 \mathrm{~L} .40 \mathrm{~mL}$ of $100 \mathrm{mg} / \mathrm{L} \mathrm{Zn}^{2+}$ solution was placed in a $200 \mathrm{~mL}$ conical flask. Then $0.1 \mathrm{~g}$ of amidoximemodified polyacrylonitrile/fly ash composite was added to this solution. The absorbance of the supernatant was measured at intervals. The adsorption experiments at different $\mathrm{pH}$ values were carried out under the above conditions. The initial $\mathrm{pH}$ of $\mathrm{Zn}^{2+}$ solution was adjusted in the range of 2-7. The adsorption capacity $\left(q_{e}\right)$ was obtained according to the equation:

$$
q_{e}=\frac{\left(C_{0}-C_{e}\right) V}{m}
$$

where $C_{0}$ and $C_{e}(\mathrm{~mol} / \mathrm{L})$ are the initial and equilibrium concentrations of $\mathrm{Zn}^{2+}$ ions, respectively; $V(\mathrm{~L})$ is the volume of $\mathrm{Zn}^{2+}$ solution; and $m(\mathrm{~g})$ is the mass of amidoximemodified polyacrylonitrile/fly ash composite.

\subsubsection{Effect of $\mathrm{pH}$}

Next, $40 \mathrm{~mL}$ of $100 \mathrm{mg} / \mathrm{L} \mathrm{Zn}^{2+}$ solution was placed in a $200 \mathrm{~mL}$ conical flask and $0.1 \mathrm{~g}$ amidoxime-modified polyacrylonitrile/fly ash composite was added. The $\mathrm{pH}$ of solution was adjusted to be $2,3,4,5,6$, and 7 , respectively. The adsorption proceeded under a constant temperature for a period of time and then was filtered.

\subsubsection{Dynamic Test}

Next, $40 \mathrm{~mL}$ of $100 \mathrm{mg} / \mathrm{L} \mathrm{Zn}^{2+}$ solution was placed in a $200 \mathrm{~mL}$ conical flask and $0.1 \mathrm{~g}$ amidoxime-modified polyacrylonitrile/fly ash composite was added. The $\mathrm{pH}$ of solution was adjusted to be 6 . The adsorption proceeded under a constant temperature with a different adsorption time.

\subsubsection{Effect of Temperature}

Next, $40 \mathrm{~mL}$ of $100 \mathrm{mg} / \mathrm{L} \mathrm{Zn}^{2+}$ solution was placed in a $200 \mathrm{~mL}$ conical flask, and $0.1 \mathrm{~g}$ amido-ime-modified polyacrylonitrile/fly ash composite was added. The $\mathrm{pH}$ of solution was adjusted to be 6 . The adsorption proceeded under a constant temperature with a different temperature. 


\section{Results and Discussions}

\subsection{Characterization of Amidoxime-Modified Polyacrylonitrile/Fly Ash Composite}

Figure 1 shows the FT-IR of different composites. The main component of fly ash is silica. As shown in Figure 1, the peaks at $1085 \mathrm{~cm}^{-1}$ (a in Figure 1), $1089 \mathrm{~cm}^{-1}$ (b in Figure 1), and $1116 \mathrm{~cm}^{-1}$ (c in Figure 1) correspond to Si-O coming from fly ash. The peak at $3450 \mathrm{~cm}^{-1}$ is attributed to $-\mathrm{OH}$. The peak at $2250 \mathrm{~cm}^{-1}$ (b and c in Figure 1) is ascribed to $-\mathrm{CN}$ coming from polyacrylonitrile. However, the peak at $2250 \mathrm{~cm}^{-1}$ (c in Figure 1) is greatly weakened in comparison with the peak at $2250 \mathrm{~cm}^{-1}$ (b in Figure 1).

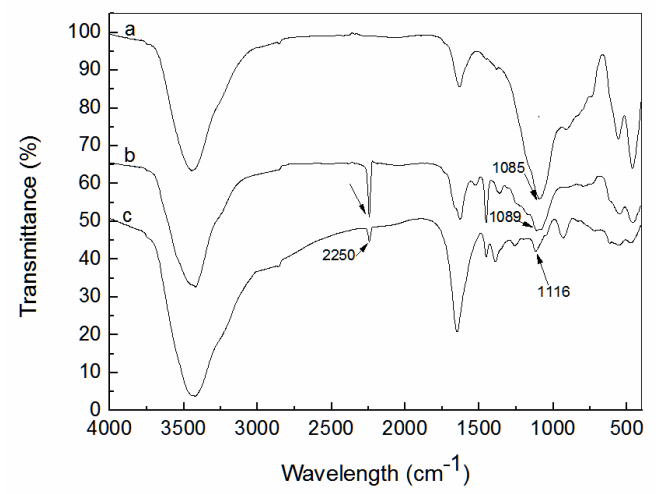

Figure 1. FT-IR spectra of FA pretreated with $\mathrm{HCl}(\mathrm{a})$, polyacrylonitrile/fly ash composite (b), and amidoxime-modified polyacrylonitrile/fly ash composite (c).

The TGA curves of fly ash and amidoxime modified polyacrylonitrile/fly ash composite are shown in Figure 2. As can be seen, the TGA curve of fly ash had little change. However, the TGA curve of modified fly ash can be divided into two stages. The first stage occurred between room temperature and $100{ }^{\circ} \mathrm{C}$. The free water in amidoxime modified polyacrylonitrile/fly ash composite changed into steam with the increase in temperature. The second stage occurred between 100 and $450{ }^{\circ} \mathrm{C}$, the chemical bonds in the amidoxime modified polyacrylonitrile/fly ash composite were broken, and the structure was destroyed with the increase in temperature to turn into small molecules to form some small organic molecules, such as $\mathrm{CH}_{4}$ and $\mathrm{CO}_{2}$. The weight loss rate of the amidoxime modified polyacrylonitrile/fly ash composite was $76.28 \%$.

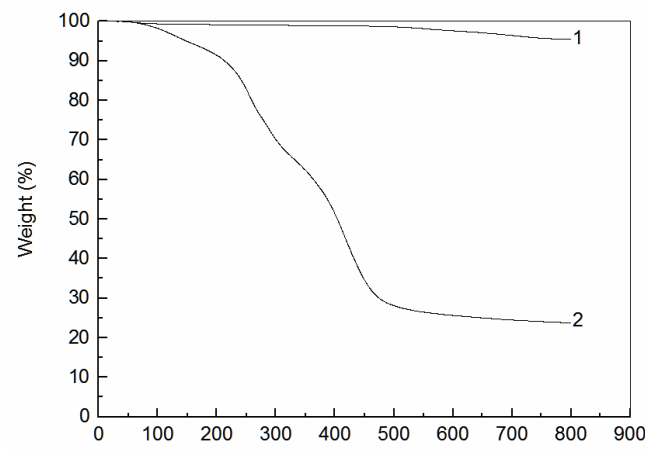

Figure 2. TGA curves of fly ash and amidoxime modified polyacrylonitrile/fly ash composite. (1. Fly Ash; 2. Amidoxime modified polyacrylonitrile/fly ash composite.).

$\mathrm{N}_{2}$ adsorption-desorption curves and pore size distribution of amidoxime-modified polyacrylonitrile/fly ash composite are shown in Figure 3. As can be seen from Figure 3a, $\mathrm{N}_{2}$ desorption adsorption curves belonged to a type IV isothermal adsorption curve. Figure $3 b$ shows that the sample was rich in pore structure. Moreover, the pore size was mainly distributed below $10 \mathrm{~nm}$. The specific surface area calculated by BET was $4.653 \mathrm{~m}^{3} / \mathrm{g}$. The total pore volume of single point adsorption calculated by $\mathrm{BJH}$ was $0.048 \mathrm{~cm}^{3} / \mathrm{g}$, 
and the average pore size was $4.862 \mathrm{~nm}$. The XRD spectra of fly ash and amidoxime modified polyacrylonitrile/fly ash composite are shown in Figure 3c. As shown, the XRD peak of fly ash was sharp. However, the XRD peak intensity of amidoxime modified polyacrylonitrile/fly ash composite decreased. SEM graphs of fly ash and amidoxime modified polyacrylonitrile/fly ash composite are shown in Figure 4. The fly ash (left) particles were spherical, and the surface of fly ash showed relatively uniform and smooth characteristics. The surface of amidoxime modified polyacrylonitrile/fly ash composite (right) became very rough, accompanied by cracks, pits, and other phenomena. Many microporous structures were also found on its surface. This kind of irregular folded lamella was caused by the modification.

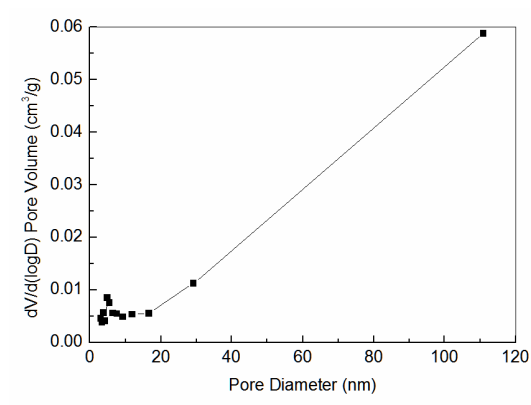

(a)

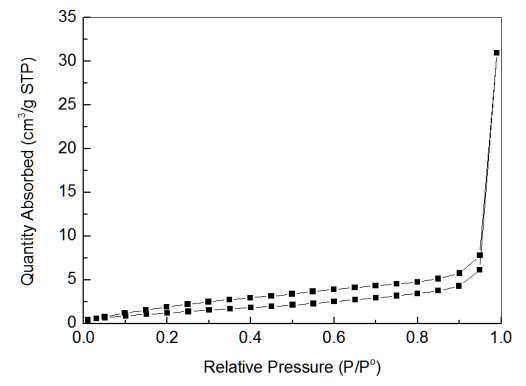

(b)

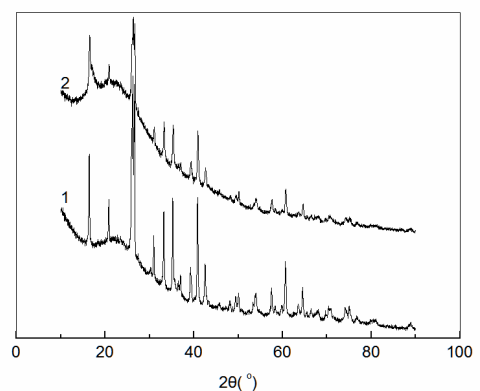

(c)

Figure 3. (a) $\mathrm{N}_{2}$ adsorption-desorption curves of amidoxime-modified polyacrylonitrile/fly ash composite; (b) Pore size distribution of amidoxime-modified polyacrylonitrile/fly ash composite; (c) XRD curves of fly ash and amidoxime modified polyacrylonitrile/fly ash composite. (1. Fly Ash; 2. Amidoxime modified polyacrylonitrile/fly ash composite.).
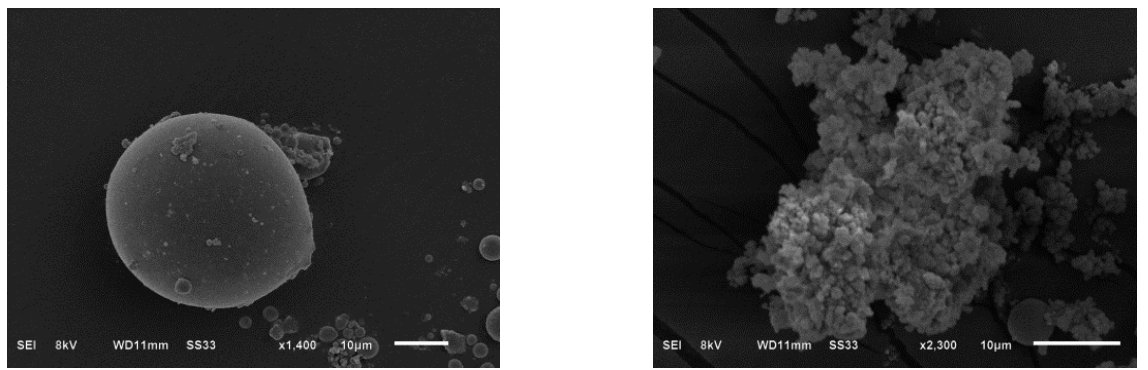

Figure 4. Particle morphology of fly ash (left) and amidoxime modified polyacrylonitrile/fly ash composite (right) demonstrated by SEM graphs.

\subsection{Effect of Initial $p H$ on Adsorption}

The effect of the initial solution $\mathrm{pH}$ on $q_{e}$ was investigated. The result is shown in Figure 5. The $q_{e}$ increased when the initial $\mathrm{pH}$ increased from 2 to 4 . However, the increase in adsorption capacity slowed down when the initial $\mathrm{pH}$ exceeded 4 . The $q_{e}$ decreased when the initial $\mathrm{pH}$ exceeded 6 . The $q_{e}$ of $\mathrm{Zn}^{2+}$ is related to its existing form 
in solution. The large amount of $\mathrm{H}^{+}$in aqueous medium made the functional groups on the surface of amidoxime-modified polyacrylonitrile/fly ash composite protonated at $\mathrm{pH}<4$. The adsorbable $\mathrm{Zn}^{2+}$ sites decreased on the one hand, on the other hand, $\mathrm{H}+$ competed with $\mathrm{Zn}^{2+}$ for the limited adsorption sites on the surface of amidoxime-modified polyacrylonitrile/fly ash composite. As a result, the $q_{e}$ of $\mathrm{Zn}^{2+}$ decreased with the decrease in $\mathrm{pH}$ value. When the $\mathrm{pH}$ value was in the range of 4 to 6 , the surface functional groups of amidoxime-modified polyacrylonitrile/fly ash composite were gradually deprotonated. The $q_{e}$ of $\mathrm{Zn}^{2+}$ also increased. When the $\mathrm{pH}$ was greater than 6 , the formation of zinc hydroxides on the composite surface was not conducive to the adsorption of $\mathrm{Zn}^{2+}$, resulting in reduced $q_{e}$.

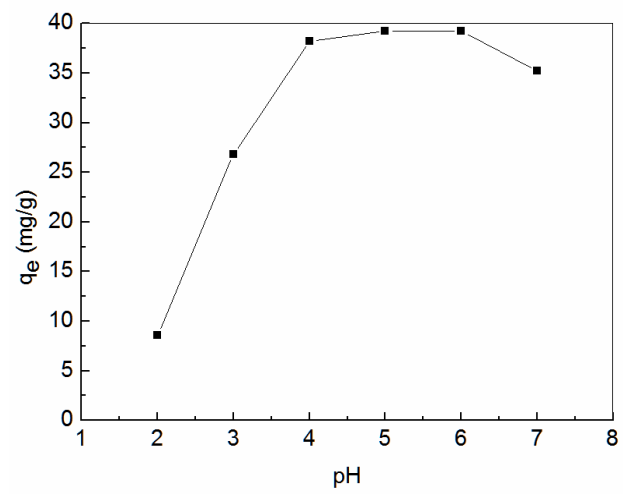

Figure 5. Effect of initial solution $\mathrm{pH}$ on equilibrium adsorption capacity $\left(q_{e}\right)$.

\subsection{Effect of Coexisting Ions on Adsorption of $\mathrm{Zn}^{2+}$}

When the initial concentration of $\mathrm{Zn}^{2+} \mathrm{C} 0$ was $100 \mathrm{mg} \cdot \mathrm{L}^{-1}$, the adsorption temperature was $25^{\circ} \mathrm{C}$, the nitrates of $\mathrm{Na}^{+}, \mathrm{K}^{+}$, and $\mathrm{Ca}^{2+}$ were added, respectively, the addition amount was $50 \mathrm{mg} \cdot \mathrm{L}^{-1}$. The $\mathrm{pH}$ value of solution was adjusted by hydrochloric acid and sodium hydroxide. The influence of cations on the adsorption of $\mathrm{Zn}^{2+}$ by amidoxime-modified polyacrylonitrile/fly ash composite was investigated. The experimental results are shown in Figure 6. As can be seen, except for $\mathrm{NH}_{4}{ }^{+}$, other cations were not conducive to the adsorption of $\mathrm{Zn}^{2+}$ by amidoxime-modified polyacrylonitrile/fly ash composite, because coexisting cations competed with the adsorption of $\mathrm{Zn}^{2+}$, which reduced the number of adsorption sites on the surface of amidoxime-modified polyacrylonitrile/fly ash composite. Under the condition of weak acid, $\mathrm{NH}_{4}{ }^{+}$mainly existed as $\mathrm{NH}_{3} \cdot \mathrm{H}_{2} \mathrm{O}$, which had little effect on the adsorption of $\mathrm{Zn}^{2+}$ by amidoxime-modified polyacrylonitrile/fly ash composite, but the adsorption capacity of $\mathrm{Zn}^{2+}$ slightly increased.

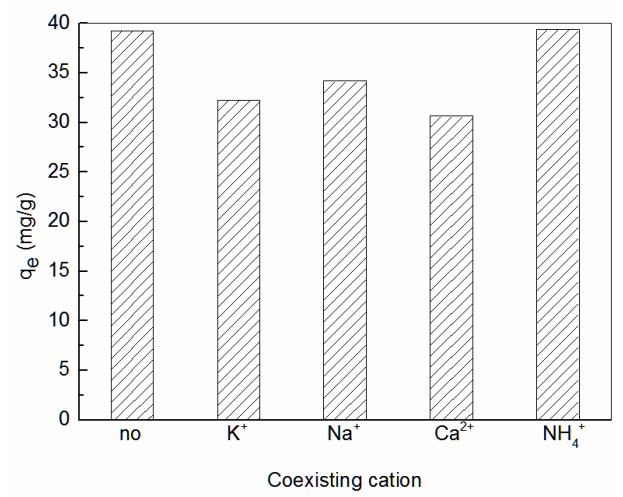

Figure 6. Effect of coexisting anion on the adsorption of $\mathrm{Zn}^{2+}$ by amidoxime-modified polyacrylonitrile/fly ash composite. 


\subsection{Effect of Contact Time on Adsorption}

Figure 7 shows the effect of adsorption time on the $q_{e}$ of $\mathrm{Zn}^{2+}$ by amidoxime-modified polyacrylonitrile/fly ash composite. As can be seen, the adsorption process of $\mathrm{Zn}^{2+}$ by adsorbent can be roughly divided into three stages: fast stage, dynamic equilibrium stage, and slow stage. The $q_{e}$ increased gradually within the initial $20 \mathrm{~min}$ and then tended to be stable with the extension of adsorption time. There were several adsorption sites on the surface of the adsorbent at the beginning of adsorption. It is also beneficial for the $\mathrm{Zn}^{2+}$ to enter into the particle through the pores. As the adsorption proceeded, the available sites on the surface of amidoxime-modified polyacrylonitrile/fly ash composite were exhausted. The adsorption rate of $\mathrm{Zn}^{2+}$ was manipulated by the rate at which $\mathrm{Zn}^{2+}$ was absorbed from the outer to the inner adsorbable sites of amidoxime-modified polyacrylonitrile/fly ash composite. The adsorption rate slowed. To ensure the establishment of the adsorption equilibrium, the experimental adsorption vibration time was set to be $120 \mathrm{~min}$.

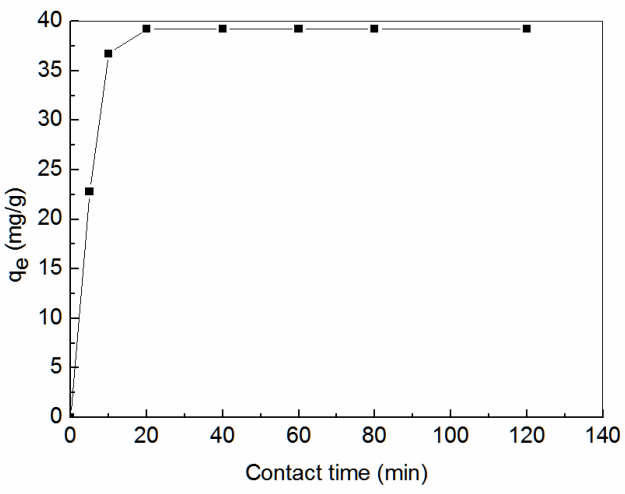

Figure 7. Effect of contact time on equilibrium adsorption capacity $\left(q_{e}\right)$.

\subsection{Adsorption Kinetics}

The adsorption data were fitted by the pseudo-first order kinetic model (Equation (1)) [47], pseudo-second order kinetic model (Equation (2)) [48], and the Elovich equation (Equation (3)) [49], respectively.

$$
\begin{gathered}
\ln \left(q_{e}-q_{t}\right)=\ln q_{e}-k_{1} t \\
\frac{t}{q_{t}}=\frac{1}{k_{2} q_{e}^{2}}+\frac{t}{q_{e}} \\
q_{t}=\frac{1}{\beta} \ln t+\frac{1}{\beta}(\alpha \beta)
\end{gathered}
$$

where $q_{e}$ and $q_{t}(\mathrm{mg} / \mathrm{g})$ are the amount of adsorbate adsorbed at equilibrium and any time $t$ ( $\mathrm{min}$ ), respectively; $k_{1}$ and $k_{2}$ are the pseudo-first order kinetic adsorption rate constant $\left(\mathrm{min}^{-1}\right)$ and the pseudo-second order kinetic adsorption rate constant $[\mathrm{g} /(\mathrm{min} \cdot \mathrm{mg})]$, respectively; $\mathrm{t}$ is the adsorption time ( $\mathrm{min})$; and $\alpha$ and $\beta$ are the parameters of the adsorption kinetic model.

Three models were used to fit the dynamic data of amidoxime-modified polyacrylonitrile/fly ash composite, and the fitting results and corresponding parameters are shown in Figure 8 and Table 1. It was found that the adsorption process of $\mathrm{Zn}^{2+}$ by amidoxime-modified polyacrylonitrile/fly ash composite was more in line with the pseudosecond-order model, and the correlation coefficients $\mathrm{R}^{2}$ were all above 0.99 . Moreover, the experimental value $\left(q_{e, \exp }\right)$ and the theoretical value $\left(q_{e, c a l}\right)$ differed little. The results indicate that the adsorption of $\mathrm{Zn}^{2+}$ on amidoxime-modified polyacrylonitrile/fly ash composite involved the diffusion of the outer liquid membrane and surface adsorption. Furthermore, the parameter $\alpha$ of the Elovich equation was much larger than $\beta$, indicating that the initial adsorption rate was very fast, which was consistent with the experimental results. 


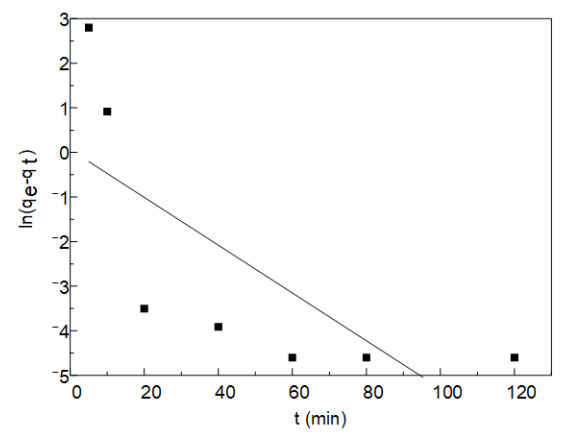

(a)

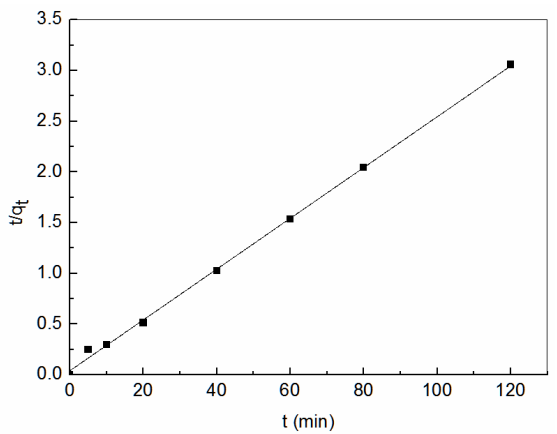

(b)

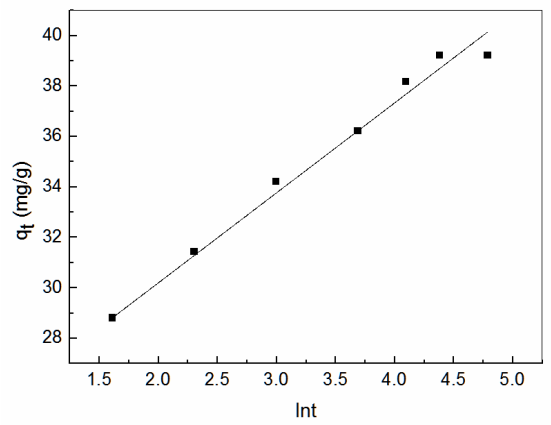

(c)

Figure 8. (a) Linear fit of pseudo-first order equation; (b) Linear fit of pseudo-second order equation; and (c) Linear fit of Elovich equation.

Table 1. Kinetic constants for adsorption of $\mathrm{Zn}^{2+}$ ions.

\begin{tabular}{cccccccccc}
\hline $\begin{array}{c}\text { Kinetic } \\
\text { Model }\end{array}$ & \multicolumn{3}{c}{ Pseudo-First Order Kinetic } & \multicolumn{2}{c}{ Pseudo-Second Order Kinetic } & \multicolumn{2}{c}{ Elovich Equation } \\
\hline $\begin{array}{c}q_{e, \text { exp }} \\
(\mathrm{mg} / \mathrm{g})\end{array}$ & $k_{1}$ & $\begin{array}{c}q_{e, \mathrm{cal}} \\
\left(\mathrm{min}^{-1}\right)\end{array}$ & $\begin{array}{c}(\mathrm{mg} / \mathrm{g}) \\
\mathrm{R}^{2}\end{array}$ & $\begin{array}{c}k_{2} \\
\mathrm{~g} /(\mathrm{min} \cdot \mathrm{mg})\end{array}$ & $\begin{array}{c}q_{e, \mathrm{cal}} \\
(\mathrm{mg} / \mathrm{g})\end{array}$ & $\mathrm{R}^{2}$ & $\alpha$ & $\beta$ & $\mathrm{R}^{2}$ \\
39.81 & 0.0536 & 1.0644 & 0.4453 & 0.0250 & 39.92 & 0.9985 & 2297 & 0.2803 & 0.9785 \\
\hline
\end{tabular}

\subsection{Adsorption Isotherm}

The isothermal adsorption curve refers to the relationship between the concentrations of solute molecules in two phases when the adsorption process on the interface reaches equilibrium at a certain temperature. The adsorption isotherm is helpful to understand the nature of the adsorption phenomenon, and the adsorption capacity of amidoxime-modified polyacrylonitrile/fly ash composite at a specific concentration of $\mathrm{Zn}^{2+}$ can be calculated by the isotherm adsorption model.

The linearized Langmuir [50] and Freundlich [51] isotherms are given by Equation (5) and Equation (6), respectively.

$$
\begin{aligned}
\frac{C_{e}}{q_{e}} & =\frac{1}{q_{\text {max }} b}+\frac{C_{e}}{q_{\text {max }}} \\
\ln q_{e} & =\ln K+\frac{1}{n} \ln C_{e}
\end{aligned}
$$

where $q_{e}$ is the equilibrium adsorption capacity $(\mathrm{mg} / \mathrm{g}), C_{e}$ is the concentration of $\mathrm{Zn}^{2+}$ ions in the solution at equilibrium $(\mathrm{mol} / \mathrm{L}), q_{\max }$ is the maximum adsorption capacity $(\mathrm{mg} / \mathrm{g})$, and $b$ is a constant related to the free energy of adsorption. $K$ is a constant related to adsorption capacity and adsorption strength; and $\mathrm{n}$ is the Freundlich constant.

The Langmuir and Freundlich models were used to fit the adsorption data of $\mathrm{Zn}^{2+}$ at $25{ }^{\circ} \mathrm{C}, 35^{\circ} \mathrm{C}$, and $45^{\circ} \mathrm{C}$. The fitting results are shown in Figure 9 and Table 2. As shown, the coefficient of correlation $\mathrm{R}^{2}$ of Langmuir model was greater than that of the 
Freundlich model, indicating that the adsorption data were more consistent with the Langmuir isothermal adsorption model. The Langmuir isothermal adsorption equation assumes that the adsorption is monolayer, solute and solvent molecules have approximately the same volume or the same adsorption site; the adsorption of solute is regarded as the result of the exchange between solute molecules in the solution and the adsorbed solvent molecules in the adsorption layer. Table 2 summarizes some of the recent results of $\mathrm{Zn}^{2+}$ removal from wastewater using fly ash.

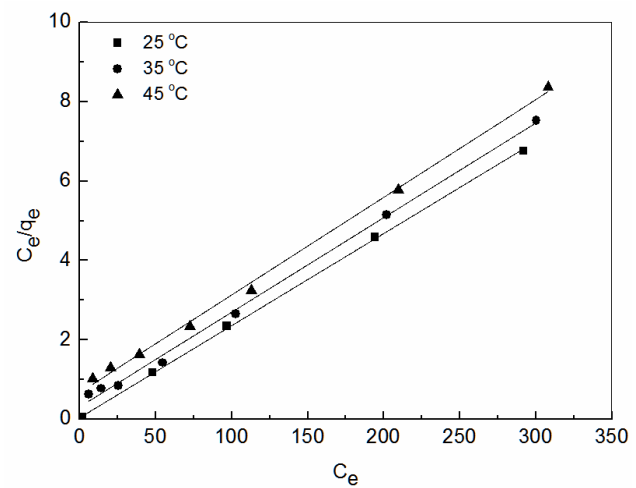

Figure 9. Linearized Langmuir isotherms obtained from $\mathrm{Zn}^{2+}$ adsorption on amidoxime-modified polyacrylonitrile/fly ash composite.

Table 2. Summary of $\mathrm{Zn}^{2+}$ adsorption on fly ash according to references and present study.

\begin{tabular}{ccc}
\hline Adsorbent & Adsorption Capacity (mg/g) & Reference \\
\hline ZIF-8/fly ash composite & 197 & {$[52]$} \\
lime activated fly ash & 33.13 & {$[53]$} \\
fly ash-based geopolymer & 35.18 & {$[54]$} \\
modified fly ash & 13.38 & {$[55]$} \\
amidoxime-modified & 43.08 & This work \\
polyacrylonitrile/fly ash composite & & \\
\hline
\end{tabular}

According to the Langmuir theory, it is speculated that $\mathrm{Zn}^{2+}$ is uniformly adsorbed on the active site $\left(\mathrm{NH}_{2}-\mathrm{C}=\mathrm{N}-\mathrm{OH}\right)$ on the surface of amidoxime-modified polyacrylonitrile/fly ash composite. When all the active sites are adsorbed on $\mathrm{Zn}^{2+}$, the adsorption amount reaches saturation, and the adsorption is in equilibrium. In Table 3, both the Langmuir adsorption constant $b$ and the adsorption capacity qmax decreased with the increase in temperature, indicating that the temperature rise was not conducive to the adsorption process.

Table 3. Equilibrium parameters for adsorption of $\mathrm{Zn}^{2+}$.

\begin{tabular}{ccccccc}
\hline \multirow{2}{*}{$\mathbf{T}\left({ }^{\circ} \mathbf{C}\right)$} & \multicolumn{3}{c}{ Langmuir Model } & \multicolumn{3}{c}{ Freundlich Model } \\
\cline { 2 - 7 } & $\boldsymbol{q}_{e, \text { cal }}$ & $\boldsymbol{b}$ & $\mathbf{R}^{\mathbf{2}}$ & $\boldsymbol{K}$ & $\boldsymbol{n}$ & $\mathbf{R}^{\mathbf{2}}$ \\
\hline 25 & 43.08 & 0.6090 & 0.9997 & 21.96 & 7.115 & 0.6189 \\
35 & 41.93 & 0.0762 & 0.9971 & 7.38 & 2.961 & 0.7441 \\
45 & 40.65 & 0.0366 & 0.9970 & 4.49 & 2.462 & 0.8617 \\
\hline
\end{tabular}

The essential characteristic of the Langmuir isothermal adsorption is that it can be expressed as a dimensionless constant $P_{L}$. It can characterize the adsorption performance, predicting the binding force of adsorbent and adsorbent:

$$
P_{L}=\frac{1}{1+b C_{0}}
$$


where $P_{L}$ is the Langmuir isothermal adsorption constant and $C_{0}$ is the initial concentration of the solution $(\mathrm{mol} / \mathrm{L})$.

When $0<P_{L}<1$, adsorption is easy under the experimental conditions studied. The initial concentration at each temperature was selected, and $P_{L}$ was calculated to be $0.004 \sim 0.0051,0.038 \sim 0.3043$, and 0.0639 0.4766, respectively. It can be seen that $P_{L}$ is between 0 and 1 , and $P_{L}$ decreased with the increase in $\mathrm{Zn}^{2+}$ concentration at the same temperature, indicating that the increase in the initial concentration of $\mathrm{Zn}^{2+}$ in the adsorption solution was conducive to the adsorption, and adsorption was favorable under the whole test conditions.

\subsection{Thermodynamics}

The direction and difficulty of the adsorption reaction can be judged by the thermodynamic parameters such as Gibbs free energy change $\Delta G$, enthalpy change $\Delta H$, and entropy change $\Delta S$.

The Vant Hoff equation is calculated as follows:

$$
\begin{gathered}
\Delta G^{0}=\ln b \\
\ln b=\frac{\Delta H^{0}}{R T} \frac{\Delta S^{0}}{R} \\
b=q_{e} / C_{e}
\end{gathered}
$$

where $R$ is the gas constant $[8.314 \mathrm{~J} /(\mathrm{mol} \cdot \mathrm{K})] ; T$ is temperature $(K) ; b$ is Langmuir isothermal adsorption constant; and $\Delta H$ and $\Delta S$ can be obtained from the slope and intercept of lnb and $1000 / \mathrm{T}$, respectively.

The fitting results are listed in Table 4 . The negative value of $\Delta H^{0}$ indicated that the adsorption reaction of $\mathrm{Zn}^{2+}$ was exothermic. Adsorption Gibbs free energy $\Delta G^{0}$ is the embodiment of the adsorption driving force and adsorption preference, and $\Delta G^{0}$ was negative, which indicated that the adsorption process of $\mathrm{Zn}^{2+}$ was spontaneous. Furthermore, $\Delta G^{0}$ increased with the increase in temperature, indicating that the reaction was more easily

\begin{tabular}{|c|c|c|c|c|}
\hline $\mathrm{T}\left({ }^{\circ} \mathrm{C}\right)$ & $b$ & $\Delta G^{0}(\mathrm{~kJ} / \mathrm{mol})$ & $\Delta H^{0}(\mathrm{~kJ} / \mathrm{mol})$ & $\Delta S^{0}(\mathrm{~J} /(\mathrm{mol} \cdot \mathrm{K}))$ \\
\hline 25 & 609 & -15.885 & & \\
\hline 35 & 76.2 & -11.096 & -116.88 & -334.27 \\
\hline 45 & 36.6 & -9.518 & & \\
\hline
\end{tabular}
carried out at low temperature (Figure 10).

Table 4. Thermodynamic parameters for adsorption of $\mathrm{Zn}^{2+}$.

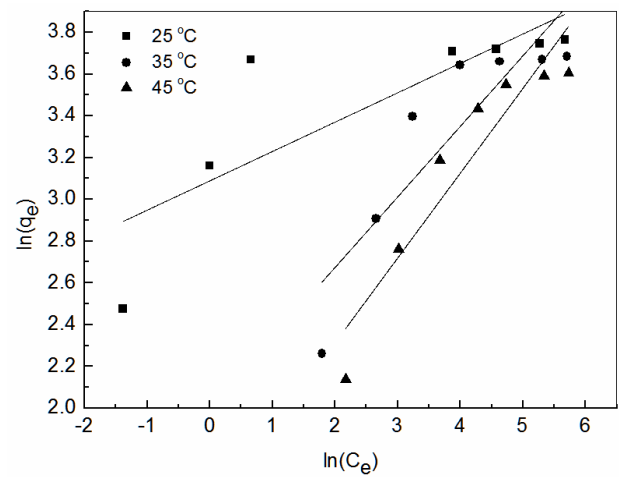

Figure 10. Linearized Freundlich isotherms obtained from $\mathrm{Zn}^{2+}$ adsorption on amidoxime-modified polyacrylonitrile/fly ash composite.

Entropy change $\Delta S^{0}$ is the algebraic sum of entropy change of the whole system process, which reflects the change of the chaos degree of the existing state in the system. 
The $\Delta S^{0}$ is small and the system is in a relatively ordered state. The $\Delta S^{0}$ is large and the system is in a relatively disordered state. $\Delta S^{0}$ is negative, indicating that the order degree of the whole solution system is improved through the adsorption of $\mathrm{Zn}^{2+}$ by the adsorbent. According to the exchange theory, absorption for solid-liquid exchange adsorption, solute molecules from solution phase adsorption exchange to lose part of solid-liquid interface degrees of freedom, this is a process of entropy, at the same time, on the adsorbent adsorption $\mathrm{Zn}^{2+}$, to a large number of water molecules on the adsorbent desorption, the original on the surface of the adsorbent and tidy, compact arrangement of water molecules desorption to freedom of movement was a process of increasing entropy. The entropy change of the whole system is the sum of the entropy changes of the above two processes, and its value is negative, indicating that the order of the whole system has been enhanced.

\section{Conclusions}

In this study, amidoxime-modified polyacrylonitrile/fly ash composite was prepared. The $q_{e}$ of $\mathrm{Zn}^{2+}$ can be increased by decreasing temperature and increasing $\mathrm{pH}$ and initial concentration of $\mathrm{Zn}^{2+}$. The pseudo-second order kinetic equation can better describe the adsorption process. The adsorption of $\mathrm{Zn}^{2+}$ on the composite was dominated by chemical adsorption. The negative $\Delta G^{0}$ and positive $\Delta \mathrm{H}^{0}$ indicate that the adsorption process is endothermic and spontaneous. The treatment of adsorption of $\mathrm{Zn}^{2+}$ by amidoximemodified polyacrylonitrile/fly ash composite has the advantages of simple operation, mild adsorption conditions, almost no additional energy and power consumption, no introduction of secondary pollution. This was not only a "green" method saving energy but also in line with the concept of environmental protection.

Author Contributions: Conceptualization, F.C.; data curation, X.S.; funding acquisition, F.C.; investigation, J.M. and X.S.; methodology, Y.S. and H.Y.; project administration, F.C.; software, Y.S.; supervision, F.C.; visualization, G.L.; writing—original draft, Y.S. and J.M.; writing-review and editing, G.L. and F.C. All authors have read and agreed to the published version of the manuscript.

Funding: This work was supported by the key project of Jiangsu Key Laboratory of Coal-based Greenhouse Gas Control and Utilization (2020ZDZZ03). There is no conflict of interest in this manuscript.

Institutional Review Board Statement: Not applicable.

Informed Consent Statement: Not applicable.

Data Availability Statement: Not applicable.

Conflicts of Interest: The authors declare no conflict of interest.

\section{References}

1. Baltakys, K.; Iljina, A.; Eisinas, A. Gyrolite adsorption of $\mathrm{Zn}^{2+}$ ions in acidic and alkaline solutions. Mater. Sci. 2015, 21, 123-128. [CrossRef]

2. Contreras-Bustos, R.; Espejel-Ayala, F.; Cercado-Quezada, B.; Jiménez-Becerril, J.; Jiménez-Reyes, M. Adsorption of Zn ${ }^{2+}$ from solutions on manganese oxide obtained via ozone precipitation reaction. Pol. J. Chem. Technol. 2016, 18, 46-50. [CrossRef]

3. $\mathrm{Wu}, \mathrm{X} . ; \mathrm{Li}, \mathrm{W}$.; Ou, D.; Li, C.; Hou, M.; Li, H.; Liu, Y. Enhanced adsorption of $\mathrm{Zn}^{2+}$ by salinity-aided aerobic granular sludge: Performance and binding mechanism. J. Environ. Manag. 2019, 242, 266-271. [CrossRef] [PubMed]

4. Idowu, A.A.; Temilade, F.A.; Peter, A.; Vahidhabanu, S.; Babu, B.R. Agro waste material as ecofriendly adsorbent for the removal of $\mathrm{Zn}(\mathrm{II})$ : Isotherm, kinetic, thermodynamic and optimization studies. Desalination Water Treat. 2019, 155, 250-258. [CrossRef]

5. Li, Z.; Gong, Y.; Zhao, D.; Dang, Z.; Lin, Z. Enhanced removal of zinc and cadmium from water using carboxymethyl cellulosebridged chlorapatite nanoparticles. Chemosphere 2021, 263, 128038. [CrossRef] [PubMed]

6. Medha, I.; Chandra, S.; Vanapalli, K.R.; Samal, B.; Bhattacharya, J.; Das, B.K. (3-Aminopropyl)triethoxysilane and iron rice straw biochar composites for the sorption of $\mathrm{Cr}(\mathrm{VI})$ and $\mathrm{Zn}$ (II) using the extract of heavy metals contaminated soil. Sci. Total Environ. 2021, 771, 144764. [CrossRef] [PubMed]

7. Wang, S.; Chen, W. Adsorption and purification of zinc in mining wastewater using microbial immobilization technology. Asian J. Chem. 2013, 25, 6811-6814. [CrossRef] 
8. Wu, F.; Zhang, Y.X.; Chen, Y.L.; Qian, H. Recycle of $\mathrm{Ag}^{+}$and $\mathrm{Zn}^{2+}$ with magnetic adsorbent in process of its purification from wastewater. Clean-Soil Air Water 2014, 42, 71-80. [CrossRef]

9. Mishra, U.; Paul, S.; Bandyopadhaya, M. Removal of zinc ions from wastewater using industrial waste sludge: A novel approach. Environ. Prog. Sustain. Energy 2013, 32, 576-586. [CrossRef]

10. Liu, J.; Wang, S.; Fu, J.; Ding, X.; Zhao, J. Zn ${ }^{2+}$ adsorption from wastewater using a chitosan/ $\beta$-cyclodextrin-based composite membrane. J. Food Biochem. 2020, 44, e13483. [CrossRef]

11. Sun, J.-M.; Li, F.; Huang, J.-C. Optimum $\mathrm{pH}$ for $\mathrm{Cr}^{6+} \mathrm{Co}$-removal with mixed $\mathrm{Cu}^{2+}, \mathrm{Zn}^{2+}$, and Ni ${ }^{2+}$ precipitation. Ind. Eng. Chem. Res. 2006, 45, 1557-1562. [CrossRef]

12. Rötting, T.S.; Ayora, C.; Carrera, J. Improved passive treatment of high Zn and Mn concentrations using caustic magnesia (MgO): Particle size effects. Environ. Sci. Technol. 2008, 42, 9370-9377. [CrossRef] [PubMed]

13. Yang, M.; Tang, Q.; Meng, Y.; Liu, J.; Feng, T.; Zhao, X.; Zhu, S.; Yu, W.; Yang, B. Reversible "Off-On” fluorescence of Zn²+ passivated carbon dots: Mechanism and potential for the detection of EDTA and $\mathrm{Zn}^{2+}$. Langmuir 2018, 34, 7767-7775. [CrossRef]

14. Valverde, J.L.; Lucas, A.; Gonzalez, M.; Rodriguez, J.F. Ion-exchange equilibria of $\mathrm{Cu}^{2+}, \mathrm{Cd}^{2+}, \mathrm{Zn}^{2+}$, and $\mathrm{Na}^{+}$ions on the cationic exchanger amberlite IR-120. J. Chem. Eng. Data 2001, 46, 1404-1409. [CrossRef]

15. Borba, C.E.; Silva, E.A.; Spohr, S.; Santos, G.H.F.; Guirardello, R. Ion exchange equilibrium prediction for the system $\mathrm{Cu}^{2+}-\mathrm{Zn}^{2+}{ }_{-}$ $\mathrm{Na}^{+}$. J. Chem. Eng. Data 2010, 55, 1333-1341. [CrossRef]

16. Valverde, J.L.; de Lucas, A.; Carmona, M.; González, M.; Rodríguez, J.F. Equilibrium data of the exchange of $\mathrm{Cu}^{2+}, \mathrm{Cd}^{2+}$ and $\mathrm{Zn}^{2+}$ ions for $\mathrm{H}^{+}$on the cationic exchanger Lewatit TP-207. J. Chem. Technol. Biotechnol. 2004, 79, 1371-1375. [CrossRef]

17. Malakootian, M.; Mirzaienia, F.; Malakootian, M. Removal efficiency of $\mathrm{Cu}^{2+}$ and $\mathrm{Zn}^{2+}$ from industrial wastewater by using microbial desalination cell. J. Water Chem. Technol. 2019, 41, 334-339. [CrossRef]

18. Passos, H.; Cruz, B.; Schaeffer, N.; Patinha, C.; da Silva, E.F.; Coutinho, J.A.P. Selective sequential recovery of zinc and copper from acid mine drainage. ACS Sustain. Chem. Eng. 2021, 9, 3647-3657. [CrossRef]

19. Liu, L.; Liu, S.; Peng, H.; Yang, Z.; Zhao, L.; Tang, A. Surface charge of mesoporous calcium silicate and its adsorption characteristics for heavy metal ions. Solid State Sci. 2020, 99, 106072. [CrossRef]

20. Bandura, A.V.; Sofo, J.O.; Kubicki, J.D. Adsorption of $\mathrm{Zn}^{2+}$ on the (110) surface of $\mathrm{TiO}_{2}$ (Rutile): A density functional molecular dynamics study. J. Phys. Chem. C 2011, 115, 9608-9614. [CrossRef]

21. Zeng, R.; Tang, W.; Liu, X.; Ding, C.; Gong, D. Adsorption of $\mathrm{Zn}^{2+}$ from aqueous solutions by si-substituted carbonated hydroxylapatite: Equilibrium, kinetics, and mechanisms. Environ. Prog. Sustain. Energy 2018, 37, 2073-2081. [CrossRef]

22. Ide, Y.; Ochi, N.; Ogawa, M. Effective and selective adsorption of $\mathrm{Zn}^{2+}$ from seawater on a layered silicate. Angew. Chem. 2010, 123, 680-682. [CrossRef]

23. Paton-Morales, P.; Talens-Alesson, F.I. Effect of competitive adsorption of $\mathrm{Zn}^{2+}$ on the flocculation of lauryl sulfate micelles by $\mathrm{Al}^{3+}$. Langmuir 2002, 18, 8295-8301. [CrossRef]

24. Tang, W.; Wang, X.; Zeng, G.; Liang, J.; Li, X.; Xing, W.; He, D.; Tang, L.; Liu, Z. Electro-assisted adsorption of Zn(II) on activated carbon cloth in batch-flow mode: Experimental and theoretical investigations. Environ. Sci. Technol. 2019, 53, 2670-2678. [CrossRef] [PubMed]

25. Seyedein Ghannad, S.M.R.; Lotfollahi, M.N. Preparation of granular activated carbons from composite of powder activated carbon and modified beta-zeolite and application to heavy metals removal. Water Sci. Technol. 2018, 77, 1591-1601. [CrossRef] [PubMed]

26. Song, J.; Zhang, R.; Li, K.; Li, B.; Tang, C. Adsorption of copper and zinc on activated carbon prepared from Typha latifolia L. Clean-Soil Air Water 2015, 43, 79-85. [CrossRef]

27. Luo, X.; Lei, X.; Cai, N.; Xie, X.; Xue, Y.; Yu, F. Removal of heavy metal ions from water by magnetic cellulose-based beads with embedded chemically modified magnetite nanoparticles and activated carbon. ACS Sustain. Chem. Eng. 2016, 4, 3960-3969. [CrossRef]

28. Chouyyok, W.; Shin, Y.; Davidson, J.; Samuels, W.D.; LaFemina, N.H.; Rutledge, R.D.; Fryxell, G.E.; Sangvanich, T.; Yantasee, W. Selective removal of copper(II) from natural waters by nanoporous sorbents functionalized with chelating diamines. Environ. Sci. Technol. 2010, 44, 6390-6395. [CrossRef] [PubMed]

29. García-Martín, J.; López-Garzón, R.; Godino-Salido, M.L.; Cuesta-Martos, R.; Gutiérrez-Valero, M.D.; Arranz-Mascarós, P.; Stoeckli-Evans, H. Adsorption of $\mathrm{Zn}^{2+}$ and $\mathrm{Cd}^{2+}$ from aqueous solution onto a carbon sorbent containing a pyrimidine-polyamine conjugate as ion receptor. Eur. J. Inorg. Chem. 2005, 2005, 3093-3103. [CrossRef]

30. Ji, X.D.; Ma, Y.Y.; Peng, S.H.; Gong, Y.Y.; Zhang, F. Simultaneous removal of aqueous $\mathrm{Zn}(2+), \mathrm{Cu}(2+), \mathrm{Cd}(2+), \mathrm{and} \mathrm{Pb}(2+) \mathrm{by}$ zeolites synthesized from low-calcium and high-calcium fly ash. Water Sci. Technol. 2017, 76, 2106-2119. [CrossRef] [PubMed]

31. Shubin, A.A.; Zhidomirov, G.M.; Yakovlev, A.L.; van Santen, R.A. Comparative quantum chemical study of stabilization energies of $\mathrm{Zn}^{2+}$ ions in different zeolite structures. J. Phys. Chem. B 2001, 105, 4928-4935. [CrossRef]

32. Nuryanthi, N.; Syahputra, A.R.; Oktaviani, O.; Puspitasari, T.; Pangerteni, D.S.; Kurniawan, R.; Astuti, D.A.T.; Darwis, D. Preparation of zeolite-g-polyacrylamide using radiation induced grafting and its adsorption isotherms study on several heavy metal ions. Macromol. Symp. 2020, 391, 1900139. [CrossRef]

33. Igberase, E.; Osifo, P.; Ofomaja, A. Adsorption of metal ions by microwave assisted grafting of cross-linked chitosan beads. Equilibrium, isotherm, thermodynamic and desorption studies. Appl. Organomet. Chem. 2017, 32, e4131. [CrossRef] 
34. Puspitasari, T.; Oktaviani, O.; Pangerteni, D.S.; Nurfilah, E.; Darwis, D. Study of metal ions removal from aqueous solution by using radiation crosslinked chitosan-co-poly(acrylamide)-based adsorbent. Macromol. Symp. 2015, 353, 168-177. [CrossRef]

35. Yang, T.-C.; Li, C.-F.; Chou, S.-S.; Chou, C.-C. Adsorption of metal cations by water-soluble N-alkylated disaccharide chitosan derivatives. J. Appl. Polym. Sci. 2005, 98, 564-570. [CrossRef]

36. Yildirim, M.Ş.; Bíçer, Y.; Yildiz, C. Utilization of fly ash and polypropylene wastes in the production of a new porous composite material. J. Porous Mater. 1996, 3, 189-191. [CrossRef]

37. Patel, H. Environmental valorisation of bagasse fly ash: A review. RSC Adv. 2020, 10, 31611-31621. [CrossRef]

38. Dhariwal, A. Laboratory investigations on environmental pollutant materials: Plastics and flyash. Indian J. Environ. Prot. 2010, 30, 943-947.

39. Varis, O.; Kummu, M. The Major Central Asian River Basins: An Assessment of Vulnerability. Int. J. Water Resour. Dev. 2012, 28, 433-452. [CrossRef]

40. Deng, X.; Qi, L.; Zhang, Y. Experimental study on adsorption of hexavalent chromium with microwave-assisted alkali modified fly ash. Water Air Soil Pollut. 2018, 229, 18-23. [CrossRef]

41. Oyehan, T.A.; Olabemiwo, F.A.; Tawabini, B.S.; Saleh, T.A. The capacity of mesoporous fly ash grafted with ultrathin film of polydiallyldimethyl ammonium for enhanced removal of phenol from aqueous solutions. J. Clean. Prod. 2020, 263, 121280. [CrossRef]

42. Tang, J.; Su, M.; Wu, Q.; Wei, L.; Wang, N.; Xiao, E.; Zhang, H.; Wei, Y.; Liu, Y.; Ekberg, C.; et al. Highly efficient recovery and clean-up of four heavy metals from MSWI fly ash by integrating leaching, selective extraction and adsorption. J. Clean. Prod. 2019, 234, 139-149. [CrossRef]

43. Huil, K.; Chao, C.; Kot, S. Removal of mixed heavy metal ions in wastewater by zeolite $4 \mathrm{~A}$ and residual products from recycled coal fly ash. J. Hazard. Mater. 2005, 127, 89-101. [CrossRef]

44. Jiang, L.; Liu, P. Novel Magnetic Fly Ash/Poly(acrylic acid) Composite Microgel for Selective Adsorption of Pb(II) Ion: Synthesis and Evaluation. Ind. Eng. Chem. Res. 2014, 53, 2924-2931. [CrossRef]

45. Jiang, L.; Liu, P. Covalently crosslinked fly ash/poly(acrylic acid-co-acrylamide) composite microgels as novel magnetic selective adsorbent for $\mathrm{Pb}^{2+}$ ion. J. Colloid Interface Sci. 2014, 426, 64-71. [CrossRef] [PubMed]

46. Sruthi, P.R.; Anas, S. An overview of synthetic modification of nitrile group in polymers and applications. J. Polym. Sci. 2020, 58, 1039-1061. [CrossRef]

47. Tian, H.; Jiao, L.; Dong, D. Rapid determination of trace cadmium in drinking water using laser-induced breakdown spectroscopy coupled with chelating resin enrichment. Sci. Rep. 2019, 9, 10443. [CrossRef]

48. Li, F.; Ding, C. Optimization of ultrasonic synthesis of N-succinyl-chitosan and adsorption of $\mathrm{Zn}^{2+}$ from aqueous solutions. Desalination Water Treat. 2013, 52, 7856-7865. [CrossRef]

49. Miyake, Y.; Ishida, H.; Tanaka, S.; Kolev, S.D. Theoretical analysis of the pseudo-second order kinetic model of adsorption. Application to the adsorption of $\mathrm{Ag}(\mathrm{I})$ to mesoporous silica microspheres functionalized with thiol groups. Chem. Eng. J. 2013, 218, 350-357. [CrossRef]

50. Chien, S.H.; Clayton, W.R. Application of Elovich Equation to the Kinetics of Phosphate Release and Sorption in Soils. Soil Sci. Soc. Am. J. 1980, 44, 265-268. [CrossRef]

51. Ruthven, D.M. Principles of Adsorption and Adsorption Processes; John Wiley and Sons: Hoboken, NJ, USA, 1984.

52. Chatzopoulos, D.; Varma, A.; Irvine, R.L. Activated carbon adsorption and desorption of toluene in the aqueous phase. AIChE J. 1993, 39, 2027-2041. [CrossRef]

53. Wang, C.; Yang, R.; Wang, H. Synthesis of ZIF-8/fly ash composite for adsorption of $\mathrm{Cu}^{2+}, \mathrm{Zn}^{2+}$ and $\mathrm{Ni}^{2+}$ from aqueous solutions. Materials 2020, 13, 214. [CrossRef] [PubMed]

54. Karanac, M.; Đolić, M.; Veljovic, D.; Rajaković-Ognjanović, V.; Veličković, Z.; Pavićević, V.; Marinković, A. The removal of Zn²+, $\mathrm{Pb}^{2+}$, and $\mathrm{As}(\mathrm{V})$ ions by lime activated fly ash and valorization of the exhausted adsorbent. Waste Manag. 2018, 78, 366-378. [CrossRef] [PubMed]

55. Purbasari, A.; Ariyanti, D.; Sumardiono, S. Preparation and application of fly ash-based geopolymer for heavy metal removal. In AIP Conference Proceedings; AIP Publishing LLC: Woodbury, CA, USA, 2019; Volume 2197, p. 050006(1-5). [CrossRef] 